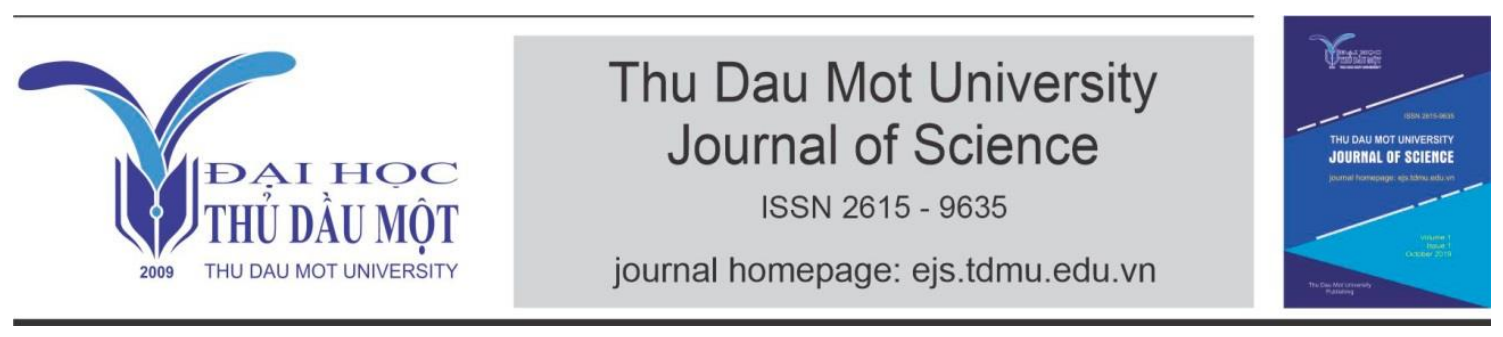

\title{
An overview about the development of theory of the novel in Vietnam
}

by Nguyễn Thị Kim Tiến (Thu Dau Mot University) Nguyễn Thị Hải Hằng (Vietnam Journal of Science, Technology and Engineering)

Article Info: Received Aug. $26^{\text {th }}, 2021$, Accepted Nov. $25^{\text {th }}, 2021$, Available online Dec. $15^{\text {th }}, 2021$

Corresponding author: tienntk@tdmu.edu.vn

https://doi.org/10.37550/tdmu.EJS/2021.04.255

\begin{abstract}
The novel is a constantly changing and evolving genre when it shows the width and depth in the reflection of reality, opening up endless dialogues about the value of human existence in its flexible structural framework. The article exploits, points out and evaluates theoretical achievements of the twentieth century novels. From this evaluation, the text identify the theoretical development trend of this genre in the twenty-first century, placed in the movement correlation, movement of contemporary Vietnamese literature seen from creative writing and receptive innovation.
\end{abstract}

Keywords: novel theory, reception in literature, Vietnamese novel

\section{Introduction}

Novel is a genre of last disappearance but quickly becomes a pioneer genre when reflecting on life because of its ability to express all aspects, thanks to its ability to synthesize all kinds in it, from there. making it an unchanging characteristic: The novel is an ever-changing genre when it shows the breadth and depth in the reflection of reality, opening up contradictions. Endless conversation about the value of human survival in its flexible structural framework.

In the research of Theory of fiction in Vietnam in the 20th century, Nguyen Van Tung (2007) has divided into three periods of development's novel theory in Vietnam. We would like to inherit above conception, accordingly, to explain more clearly about theoretical characteristics of the novel genre. On the basis of using research methodology such as: following the course of time, genre structure together with approach to 
narratology theory, combined with modern reception, exploiting articles, pointing out and evaluating theoretical achievements novel genre of twentieth century. Thereby identifying the theoretical development trend of this genre in the twenty-first century, put in the correlation of movement and development of contemporary Vietnamese literature from the perspective of creativity in writing and reception.

\section{Conception}

\section{The period from the early of $20^{\text {th }}$ century to 1945}

This period can be devided into two stages: Firsly, Early of $20^{\text {th }}$ century to 1930 , beginning to appear the first novel achievements. Secondly, From 1930 to 1945 with many brilliant achievements promoting the novel's modernization. During the period, the novel was the concept used to refer to the short story (now called the Short story) and to the Long story (now called the novel). We look at novel theory based on the second aspect.

In the book Ban ve tieu thuyet (Discuss about novel) by Pham Quynh (1921), he pointed out the characteristics of the novel, in which he introduced the concept of the novel with the very interesting observation that "the novel was an interesting but fabricated story". According to Pham Quynh, the structure is the key, which focuses on the knots. Human description should be based on human nature to describe. Describing the person who needs to describe his appearance, personality, and character before and after unitedly. This is what shows that the character building in the novels of this period is not didactic (the structure is divided into two parts: the character structure and the plot structure). In the process of literary modernization, the novel has a key role in this process and Pham Quynh's book on the novel is an important contribution to the formation and development of the theory of fiction in Vietnam.

If the function of the novel according to Pham Quynh is instructive, Thach Lam (Theo giong) believes that the novel is not only entertainment but also helps people to live, to be happy and to love. Unlike Pham Quynh's book, the character's personality is onedimensional, according to Thach Lam, the character must show many dimensions of human personality and is influenced by circumstances. In addition, the human concept is always changing, so the character always has an inner vitality and has a destiny of its own. Thach Lam's thesis has an encounter with M. Bakhtin, the person in the novel "must be described not as finished and fixed, but as a changing personality" (Pham Vinh $\mathrm{Cu}, 1992$ ). A discussion of novel theory is the Khao ve tieu thuyet (Review of novels) (Vu Bang). First, the novel character is a living character with relative independence. Second, the language of the novel is the language of truth in every class of people; Third, the novel does not need, should not follow a rigid standard, so that the novel can operate continuously. $\mathrm{Vu}$ Bang's trend is to direct the novel to follow the spirit of realism, upholding the true character (rendering the truth). This is the focus that 
Vietnamese novels in the spirit of critical realism follow (the case of Vu Trong Phung's novel). On the other hand, $\mathrm{Vu}$ Bang's remarkable progress is similar to M. Bakhtin's assertion that the novel is a constant movement and innovation. It is a freedom. This freedom is the only evident in the third and fourth stages, after the doi moi period. In Nha van hien dai (Modern writter), Vu Ngoc Phan affirmed the dominant position of modern novels, clearly marked by the classification of novels: customary novels, thesis novels, reportage novels, and animated novels. statistics, social novels, emotional novels, spiritual novels. This classification of his shows the development of modern Vietnamese fiction in a particular line of genre style at this period.

Thus, in the first phase, novel is often considered and focused on the role and function of itselt, the tendency to reflect more towards reality (describe the truth), especially the character element that needs to be built like that. When placed in the social context, Vietnamese novel has received the most attention from many works and theoretical researchers, besides aiming to perfect the language in it.

\section{The period from 1945 to 1985}

This was the period of the whole country's resistance against the French colonialists and the American imperialists. The great victory in the spring of 1975 was the proof of a fierce but glorious historical period of our nation's national defense war; at the same time affirming the spirit of the national community, the people's faithful patriotism; The Communist Party's leadership on all fronts, including culture and art, follows the ideal of socialist realism.

At this stage, novel theory solves problems serving the need to promote the creation and reception of novels according to the goal of the national liberation revolution. This period is impossible not to mention the novel in the South of Vietnam, especially from 1954 to 1975 . Novels of this period also attracted the attention of many critical theorists with a number of typical works such as Nhan vat trong tieu thuyet (Characters in fiction (Authors, Creation Publishing No. 1/160); Viet va doc tieu thuyet (Writing and reading novels (Nhat Linh, Today's Publishing, 1961); Hien huu cua tieu thuyet (Existence of the novel (Le Tuyen, University No. April 1961); Tieu thuyet Viet Nam the he 1932 1945 (Vietnamese novels of the generation 1932 -1945 (Thanh Lang, University No. 2, April 1961); Tieu thuyet hien dai Modern novels (Trang Thien, New Times Publishing, 1963); Xay dung tac pham tieu thuyet (Developing novels (Nguyen Van Trung, Nam Son Publishing, 1965); Su hinh thanh cua tieu thuyet moi (The formation of new novels) in Viet Nam van hoc su gian uoc tan bien (Vietnam's literary history (Pham The Ngu, Quoc hoc Tung thu Publishing, 1965); Chuyen phiem ve tieu thuyet (Gossip about novels (Trieu Son, Van magazine No. 34, published on May 15, 1965); Van hoc va tieu thuyet (Literature and novels (Doan Quoc Sy, Creation Publishing, 1973)... In these works, many theoretical issues about novels are posed with a multi-faceted, multi- 
dimensional view such as: conception of novel, characters and methods of building novel characters, plots in novels... Nguyen Luong Ngoc in Nguyen ly van hoc (Literary Principles (1959) pointed out that the novel is not only/not the only genre of the bourgeoisie but also a popular genre. Therefore, the novel's characters are not only kings and queens but also all classes of people to reflect reality in the richest way. Because the novel has a large volume, it unifies many genres into itself: lyrical content, dramatic, lyrical externality. The way of narration in a novel can be in the first or third person, or both. Going to the work of the novelist of Nguyen Dinh Thi, he gave the concept of this genre as follows: the novel is an ever-changing genre that directly reflects the spiritual life of society; it can absorb new achievements from the sciences and arts. In terms of characters, according to him, in addition to building a writer's appearance, language... the most important and difficult thing is to build the inner world, inner happenings, and inner psychology of the character. According to Nguyen Dinh Thi, for novels to build and write about a new life, new people need to follow the principle of expression of the realist method of composition. This important contribution of his has served as the basis for illuminating the novels of this period, in terms of reflecting the wider society, in harmony with ideal romanticism and realism; relationship between character's life and plot... For example, a few novels such as: Giong to (Vu Trong Phung's name of novel) paved the way for a novel with a monumental structure after 1960. The modern art of Vietnamese fiction has reached its peak with So do (the Red number novel). The art of footwork in the literature is also successfully demonstrated in a number of works by Ngo Tat To, Nguyen Hong, Nguyen Cong Hoan, To Hoai, Manh Phu Tu, Nguyen Dinh Lap, Lan Khai... Phan Cu De said, "These are the first novels in Vietnam that fulfill Engles' request for realistic works: to build typical personalities in typical circumstances". In the work of Tieu thuyet Viet Nam hien dai (Modern Vietnamese Fiction), Phan $\mathrm{Cu}$ De mentioned this genre characteristic. Based on Bakhtin's assessment of self-parody, about the ongoing reality reflected in the novel, Phan $\mathrm{Cu}$ De affirmed that the novel is a literary genre that is closest to life even though it is a young and growing genre. The novel character is a kind of life experience for himself, as in real life, built on the character principle of socialist realism. Specifically, the relationship between personality and circumstances is always shown in the direction of upward development, the character has ideals, acts and improves, overcomes the situation. Accordingly, the plot of the novel moves according to the development of the character's personality. If in the work of the novelist, Nguyen Dinh Thi mentioned the importance of the character's inner world, in this work, Phan $\mathrm{Cu} \mathrm{De}$ said that the novel should pay attention to the development of character psychology, such as the "dialectical of the soul" in the novel, emotional, character psychology in War and Peace by master novelist L. Tolstoi. Accordingly, the researcher emphasizes the dialectical relationship, internal logic between psychology and actions of characters, 
between typical personality and typical situation according to socialist tendency. The novelty of this work is the more elaborate mention of the novel's structure. The overall structure of a novel needs to be consistent between the elements of content and form, from the novel's theme, characters, plot to language, rhythm, and narration. It can be said that this is a theoretical work of fiction that has made a very important contribution in Vietnam when it comes to identifying issues of the artistic nature of novels in general and socialist realist novels in particular. The author's thorough research has at the same time led to a comprehensive assessment of the achievements of Vietnamese fiction writing since the beginning of the twentieth century.

Starting from the purpose of describing different conceptions of the novel, Building a novel by Nguyen Van Trung aims at the technique of building a novel by developing an approach from human conception to creative method. Accordingly, the concept of "belief in people", Nguyen Van Trung considers in individualist romantic group novels (typically Tu Luc Van Doan) and the social description group (typically critical realism), "the novel is the scene" - the role of the reader and the writer is to stand outside to see. Possibly an assimilated look (the writer impersonates the character, usually the main character); look from a distance (the novelist is just a person who narrates the story and lets the character speak for itself). With this writing approach, the novel's character is the vehicle and the happened things that are completely decided by the writer. In the concept of "skepticism about people", Nguyen Van Trung considers "the novel is a consciousness". Therefore, the novel is a dialogue between one character and the other about the meaning of life, especially the fate of being human, the writer is not describing the scene but the dialogue, especially the inner monologue; There is no longer a distance between author and reader when the time of events is not in any order instead of familiar space, inner space and opposites are evoked more to express thoughts and feelings about human existence. Viewed objectively, this concept of Nguyen Van Trung as a theoretical tool bar on the novel to examine the social existential novels in the southern urban areas in the years 1954-1975 more clearly. With the third concept "the absence of people", the novelist uses the technique of "the novel is an anti-fiction". This is, in fact, a view the researcher took on influence from A. Grillet, a modern novelist who pioneered the new novel movement in the West.

If one looks at Vietnamese novels in the period 1945-1985, even until the end of the twentieth century in terms of composition, it is difficult to find works that tend to use this construction technique, but in the early of the twenty-first century, many Vietnamese novelists boldly tried to organize their novels in a structured way. It is a novel that re-createed the "lost" characters, not necessarily going into psychological and emotional analysis and not too many details to tell; The chronological sequence is reversed, the object space sometimes appears thicker, showing a more focused look/way of looking at the character (human). This third concept is not necessarily suitable for 
Vietnamese literature in the period 1945 - 1985, because after all, all concepts are based on social and cultural circumstances. Therefore, if we refer to contemporary Vietnamese literature, Nguyen Van Trung's contribution from the novelist's perspective and approach to novels is really meaningful and valuable. In the same year 1972, Doan Quoc Sy released Literature and Novels, which is a work of collecting and rearranging the conceptions of novels of previous authors along with the writer's comments to better understand the views of concept. Such as a novel is an imaginary story but always describes closely to reality, the close relationship between the characters and the plot as well as the way of classifying the novel's characters and classifying the style of novel.

Thus, in the second period, novels are often viewed from a critical perspective through elements included in the novel such as characters, plots, and time, in addition to being associated with the themes and themes of the literature of this period, on the basic that some researchers have the opportunity to introduce and receive foreign literary theories, especially Russian literature, thereby contributing to clarifying the superior position of the novel at this period through the genre theory research.

\section{The period from 1986 to in the end of $20^{\text {th }}$ century}

The renewal has created a democratized spirit for literature has opened up opportunities for artists and intellectuals to receive the quintessence of human culture in many countries. Accordingly, the literary theory system in general and genre theory in particular have been introduced and updated with the achievements of modern Western literary theory, in which the mention of genre characteristic in the novel is an important basis for theoretical issues of Vietnamese novels (both in terms of creation and reception) to consider, re-evaluate and come to a synthesis of achievements for a novel thinking innovation.

For example, there are research works on novels that have been translated and introduced in Vietnam such as Ly luan va thi phap tieu thuyet (Theory of Novels (by M. Bakhtin selected and introduced by Pham Vinh $\mathrm{Cu}$ ); Nhung van de thi phap Dostoievxki (Poetic issues of Dostoievxki (Tran Dinh Su, Lai Nguyen An, Vuong Tri Nhan translated); Tieu luan (Essay by Milan Kundera (Translated by Nguyen Ngoc). Since then, it has led to the appearance of a lot of research works on understanding the art of creating novels, not only Western novels of the 20th century such as Doi moi nghe thuat tieu thuyet phuong Tay hien dai (Renovating the art of modern Western novels (Dang Anh Dao), Tieu thuyet Phap hien dai - nhung tim toi doi moi (Fiction Modern French - Innovative discoveries (Phung Van Tuu), Tieu thuyet Phap the ky XX truyen thong va cach tan (20th century French novels - Tradition and innovation (Loc Phuong Thuy) but also Vietnamese novels viewed from genre theory as works Ly luan van hoc (Literature Theory (many authors) have outlined five basic features of the novel. These are: i) novels that present people from the perspective of private life; ii) the novel's character is a experienced human being; 
iii) novels expressing the prose quality of life; iv) the novel bridges the gap between the narrator and the narrative object; v) Fiction is the genre with the greatest ability to synthesize other literary genres. This is the work that shows the most generalised novel's characteristics in our opinion; on the other hand, let us identify the successful application of research achievements in modern novels in the world to solve theoretical problems of Vietnamese novels. In addition, this work is the foundational theory to identify the novel genre of modern Vietnam approaching from a synchronic point of view through works that are novels in issues such as: ; character; narrator; time, space, language in the novel to the classification of novel types.

Although the theory of Vietnamese fiction appeared later than many countries with modern literature, thanks to the influence and exchange, the world's typical novel theoretical trends have been translated, introduced and researched. Research in Vietnam has brought about important achievements, positively affecting the creation, criticism and teaching of novels, on the basis of drawing from the practice of composing Vietnamese novels, thereby generalizing the characteristics of novels. of the national novel. That achievement is always a push to stimulate continuous innovation for novel thinking, not only opening up a new space for novelists but also serving as a measure of guidance and reception orientation for readers, especially while the concept of a novel is always in the "present unfinished tense" (Pham Vinh $\mathrm{Cu}$, 1992) still has a pervasive power and suggests the continuing direction of the concept of novel genre in particular along with real life. Social life is in constant motion.

\section{In the first of $21^{\text {st }}$ century}

In the trend of globalization, the innovations of Vietnamese novels from 1986 to the present are associated with the concept of "literary game": from the problems of the elements, units, and forms of the text. Literature such as structure, characters, point of view, language..., to the concept of meaning and meaning in the interaction relationship between the author - the work - the reader, is considered the solver of the art game. The concept of a game is a new consciousness in creativity, reflecting on the artistic conception of the writer with a multi-valued, non-centered, de-sacred sense, considering the novel as a "game of forms", in which, the focus is the language game in the novel. The emergence of postmodernism with prominent hidden signs clearly shown through this genre shows that this is a time when not much attention is paid to the formation of conceptions, Because, there are number of writers who seeing literature is a game without a trace, and the novel is the theoretical form of the game principle. Thanks to that, creative freedom and democracy have been promoted in the relationship between the game and the player.

From the impact of postmodern artistic thinking, the concept of people in the novel has changed. It is the concept of the complex of body and mind; The fluctuation in values, 
meaning of life and being human; Hidden tragedies and sexual instincts (Nguyen Hong Dung, 2006). Therefore, through the novels of Pham Thi Hoai, Ta Duy Anh, Nguyen Binh Phuong, Chau Dien, Ho Anh Thai, Nguyen Dinh Tu, Doan Minh Phuong, Phong Diep, etc., various types of humanity have appeared. Objects such as self-aware characters, alienated characters, gay characters, committed characters, crazy characters .., provide a different way of understanding concepts and character characteristics in novels such as: complexity, multi-faceted" and "character reduction - character thinning", have created a "character revolution" in postmodern novels, leading to a view of the character category when Readers' reception of novels has also changed compared to the traditional concept.

Thus, in the period from 1986 to present, it can be said that the concept of novels as microtexts, novels like a game, is most evident in the chaotic, assembled, and illogical narrative art... In many novels, characters are bleached, space is blurred, time is reversed, and unreal. This creates the attraction of discovering the depth of the text from the reader.

\section{Conclusion}

Genre is a category of work classification, which is "the typical form of the whole work, of the whole artistic expression (...) expressing the creative memory in the process of development (Pham Vinh $\mathrm{Cu}, 1992)$. As Bakhtin observes: "The novel is the only genre that is changing and not yet defined" (Pham Vinh $\mathrm{Cu}, 1992$ ), which is the spiritual product of the times. Acording to traditional view, the research had shown that novel genre had been a grand narrative prose, had reflected the truly vast reality through the fictional events. Therefore, traditional novel's view focused on plot, the detail development of chacracter. Now, it comes from the change of reception theory, leading to a change in writing style of novel by writers. After that, the theory of modern novel genre consider as a micro- narrative in reflecting on human life through the use of artistic forms belong to postmodern thinking. Modern and postmodern literature has brought along the basic function of the novel, not so much as a story, a well-established conception of the world and history, but also as a rich reality, complex, impossible to tell or difficult to tell, is a story that does not need a story, is the insolvability of a story, is a complex, multi-faceted type of character: subconscious - infinite knowledge, symbol-characters, non-character, dual characters (both a story character and a narrator)... From there, leading to formal "inventions" such as breaking the "epic gap", through narration, narrator; towards the so-called anti-fictions, super-fictions, new novels, post-modern novels, which are gradually having experiences arising in the generation of young writers, increasingly strong, bold in the spirit of "commitment" body", bringing a new face picture with inner movement to contemporary literary life. 


\section{References}

M. Bakhtin (1992). Lý luận và thi pháp tiểu thuyết [Theory and poetics of the novel]. (Pham Vinh Cu translated and introduce). Nguyen Du School of Writing Press.

Ngô Văn Giá (1996). Nhũng vấn đề lý luận văn học giai đoạn 1930 - 1945 [Theoretical issues of literature in the period 1930 - 1945]. Hanoi Pedagogical University Publisher.

Nguyễn Hồng Dũng (2006). Anh huởng của chủ nghĩa hậu hiện đại đối với tiểu thuyết Việt Nam tù 1986 -2010 [The influence of postmodernism on Vietnamese novels from 1986 to 2010]. Doctoral Thesis. Hue University.

Nguyễn Thị Kiều Anh (2005). Lý luận về thể loại tiểu thuyết trong nghiên cưu, phê bình Văn hoc Việt Nam đầu thế kỷ XX [Theory of novel genre in research and criticism of Vietnamese literature in the early twentieth century]. Ha Noi Nation University Publisher.

Nguyễn Văn Tùng (2001). Quan niệm về tiểu thuyết của các cây bút Tự lực văn đoàn nhìn từ thi pháp về tiểu thuyết của $\mathrm{M}$. Bakhtin [The concept of novels of Tu luc van doan writers from the poetic perspective of M. Bakhtin's novels]. Science Journal of Ha Noi Nation University, (4), 45 - 51.

Nguyễn Văn Tùng (2007). Lý luận tiểu thuyết ở Việt Nam thế kỷ XX [Theory of fiction in Vietnam in the 20th century]. Hanoi Pedagogical University Publisher. 